\title{
The Proposal How to Make the Basic Machining Technologies - Turning, Milling, Planing - More Productive
}

Karol Vasilko, Zuzana Murčinková

Faculty of Manufacturing Technologies, Technical University of Košice, 08001 Prešov, Bayerova 1, E-mail: karol.vasilko@tuke.sk, zuzana.murcinkova@tuke.sk

The current manufacturing production is characterised by increasing level of automation, emerging of the new light-weight and high-stiff materials that are technologically difficult to produce. These trends have significant impact on production productivity. The automation has brought significant reduction of non-productive time (fast workpiece and tool exchange, automatic control of product quality during technological process). In this situation, the machining time becomes the limiting factor. In present, the reducing of the machining time is possible to make only by either significant changes in conventional technologies or application of new technological principle. However, these secondary solutions in some production section are not sufficient because it requires a global solution. An example of un-equal time continuity in link production is fact that one pressing machine with the time per one piece in seconds can supply dozen of lathes with the time per one piece in minutes. The paper provides also the proposal to the productivity increase of critical technologies as turning and milling.

Keywords: productivity, machining time, technology, automation, product, material

\section{References}

[1] HOLEŠOVSKÝ, F., NAPRSTKOVÁ, N., NOVÁK, M. (2012). GISC for Grinding Process Optimalization. Manufacturing Technology 12/12. 2012, pp. 22-26, ISBN 1213-2489.

[2] KUNDRAK, J. (2011). Alternative machining procedures of hardened steels. Manufacturing Technology, 2011, 11, pp. 32-39, ISBN 1213-2489.

[3] LOLADZE, T. N. (1978). Osnovnyje voprosi optimizacii mašinostrojitelnogo proizvodstva. Sabčota Sakartvelo, 1978,245 s.

[4] Patent SR, č. 287347 Výkonná čelná fréza.

[5] Patent SR, č. 150486. Nástroj na sústruženie.

[6] PALMAI, Z. (2012). Model of chip formation during turning in the presence of a built-up edge. Manufacturing Technology. 2012, 12/2 pp. 207-212, ISBN 1213-2489.

[7] ROMGNOLO, G. Plaquette de coupe amovible pour e croutage de barres sur machine sans centre. French Patent No. 7528886.

[8] SEDLÁK, J. et al. (2015). High-Speed Cutting of Bearing Rings from Material 100Cr6. Manufacturing Technology, 2015, Vol 15, No. 5, pp. 899-908, ISBN 1213-2489.

[9] SCHULZ, H., SCHÜTZER, K. (2004). The History of High-Speed machining. Germany: Sao Paolo: Ed. Erica, 2004, Marz 2015.

[10] STANOVICS, I., KUNDRAK, J. (2013). Theoretical Value of Total Height of Profile in Rotational Turning. Applied Mechanics and Materials, 2013, Vol. 309, pp. 154-161.

[11] STEPHENSON, D. A., AGAPIOU, J. R. (2005). Metal cutting theory and practice. London, New York. Taylor \& Francis, 2005, 884 p., ISBN 0-8247-5888-9.

[12] TRENT, E. M., WRIGHT, P. K. (2000). Metal Cutting. Oxford. Butterwoth/Heinemann, 2000, 446 p., ISBN 07506-7069-X.

[13] VASILKO, K., MÁDL, J. (2012). Teorie obráběni, UJEP, Ústí nad Labem, 2012, 526 p., ISBN 978- 80-7114460-8

[14] VOJTKO, I., SIMKULET, V., KOČIŠKO, M., BARON, P. (2013). Investigation of carbon steel C45 after new turning method by master block depending on the time of acceleration amplitude of oscillation tool, World Academy of Science, Engineering and Technology, 2013, No. 78, pp. 657-659. 